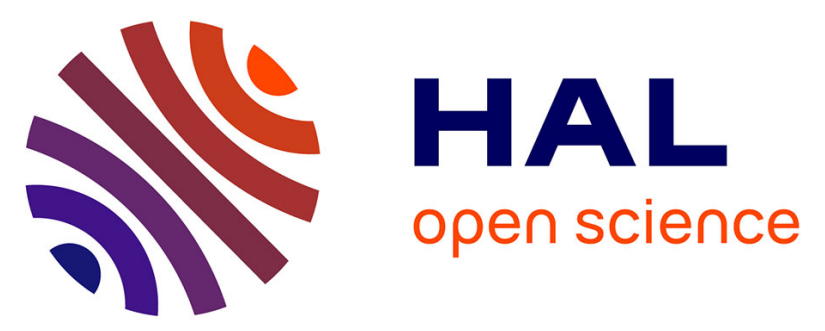

\title{
Enhanced intestinal motor response to cholecystokinin in post-Nippostrongylus brasiliensis infected rats: modulation by CCK receptors and the vagus nerve
}

Jérôme Gay-Quéheillard, Jean Fioramonti, Rafael Garcia Villar, Lionel Bueno

\section{To cite this version:}

Jérôme Gay-Quéheillard, Jean Fioramonti, Rafael Garcia Villar, Lionel Bueno. Enhanced intestinal motor response to cholecystokinin in post-Nippostrongylus brasiliensis infected rats: modulation by CCK receptors and the vagus nerve. Journal of Neurogastroenterology and Motility, 2001, 13, pp.155162. hal-02674834

\author{
HAL Id: hal-02674834 \\ https://hal.inrae.fr/hal-02674834
}

Submitted on 31 May 2020

HAL is a multi-disciplinary open access archive for the deposit and dissemination of scientific research documents, whether they are published or not. The documents may come from teaching and research institutions in France or abroad, or from public or private research centers.
L'archive ouverte pluridisciplinaire HAL, est destinée au dépôt et à la diffusion de documents scientifiques de niveau recherche, publiés ou non, émanant des établissements d'enseignement et de recherche français ou étrangers, des laboratoires publics ou privés.

\section{다(1)(2)}

Distributed under a Creative Commons Attribution - ShareAlikel 4.0 International 


\title{
Enhanced intestinal motor response to cholecystokinin in post-Nippostrongylus brasiliensis-infected rats: modulation by CCK receptors and the vagus nerve
}

\author{
J. GAY, J. FIORAMONTI, R. GARCIA-VILIAR \& L. BUÉNO
}

Neurogastroenterology and Nutrition Unit, INRA, Toulouse, France

\begin{abstract}
The jeiunal inflammation induced in rats by the nematode Nippostrongylus brasiliensis is followed by intestinal neuroimmune alterations including mast cell hyperplasia and nerve remodelling. On the other hand, cholecystokinin (CCK) plays a pivotal role in the regulation of intestinal motility. The aim of this study was to determine whether the intestinal motor response to $C C K$ is altered 30 days after infection by $N$. brasiliensis. Thus, CCK-8 (50 $\mathrm{g} \mathrm{kg}^{-1}$ intraperitoneally) disrupted the pattern of jejunal migrating myoelectric complexes for a longer time in postinfected rats $(95.5 \pm 3.5 \mathrm{~min})$ than in controls (48.1 $\pm 5.1 \mathrm{~min})$. This enhanced jejunal response was also found after oral administration of the potent releaser of endogenous $C C K$, soybean trypsin inhibitor. In contrast, no alteration of the inhibition of colonic motility by CCK administration was observed. The increased responsiveness of jejunal motility to CCK persisted after mast cell stabilisation or depletion but was prevented by atropine, devazepide and L-365260 (CCK-A and CCK-B receptor antagonists, respectively) and vagotomy. These results indicate that netroimmune alterations after $N$. brasiliensis infection lead to an increased intestinal motility response to CCK that involves a cholinergic mediation, a vagal pathway and alterations in intestinal $C C K-A$ and $C C K-B$ receptors.
\end{abstract}

Keywords CCK, CCK receptors, intestinal motility, nematode postinfection, rat, vagus nerve.

Address for correspondence

Dr Jean Fioramonti, Neurogastroenterology and Nutrition Unit, Institut National de la Recherche Agronomique, 180 chemin de Tournefeuille, BP 3, 31931 Toulouse, France. Tel.: +3356128 5149; fax: + 33561285397 .

e-mail: ffioramo@toulouse.inra.fr

Received: 21 June 2000

Accepted for publication: 16 November 2000

\section{INTRODUCTION}

Severe intestinal infections are often followed by symptoms of irritable bowel syndrome (IBS), ${ }^{1}$ characterized by abnormalities of intestinal motility and visceral hypersensitivity to various stimuli. ${ }^{2}$ There is growing evidence that these alterations in both motility and sensitivity involve neuroimmune modifications of the intestinal mucosa. ${ }^{3,4}$ An increase in mast cell numbers has been described in the intestinal mucosa of IBS patients ${ }^{5-7}$ and because of the close rela. tionships between mast cells and sensory nerve fibres, ${ }^{8}$ it has been suggested that mast cells have a major role, which would explain the motor and sensitive alterations observed in IBS patients. ${ }^{5}$ On the other hand, cholecystokinin (CCK) plays a pivotal role in the regulation of digestive physiology including intestinal motility. ${ }^{9,10}$ Its action on intestinal motility is located at the periphery or at the level of the central nervous system, ${ }_{1}^{1,12}$ and involves CCK-A and CCK-B receptors, ${ }^{13,12}$ cholinergic stimulation, ${ }^{14}$ and afferent vagal fibres. ${ }^{1.5}$ There is also evidence for involvement of CCK in the neuroimmune alterations of the intestinal wall. It has been suggested that endogenous CCK degranulates mast cells through the stimulation of CCK-B receptors ${ }^{16}$. On the other hand, CCK induces higher pain scores ${ }^{17}$ and an exaggerated motor response of the small intestine ${ }^{2}$ when injected into IBS patients compared with controls.

Rats infected with the nematode Nippostrongylus brasiliensis provide a well-known model for postinfective neuroimmune alterations of the small intestine. $N$. brasiliensis infection has been shown to induce a long-term mast cell hyperplasia for several weeks after an acute inflammation of the proximal jejunum for 2 weeks. ${ }^{18-21}$ The intestinal mastocytosis is found associated with a structural plasticity of the intestinal wall and mucosal nerve remodelling, ${ }^{22}$ increased excitability of enteric neurons, ${ }^{23}$ and an 
increase in substance $P(S P)$ content in the myenteric plexus $^{24}$ and SP-immunoreactive mucosal nerve fibres. ${ }^{25}$ Moreover, a close apposition of mast cells and nerves has been described in humans ${ }^{8}$ as well as in rats. ${ }^{26}$

It has been shown that the mastocytosis induced by nematode infection is associated with a hypersensitivity to distension limited to the jejunum, in which mast cell degranulation is involved. ${ }^{27}$ The postinfective neuroimmune alterations do not induce changes in the basal motor profile of the intestine ${ }^{28}$ but are associated with an increased intestinal motor response to acetylcholine. ${ }^{21}$

Taken together, these elements lead us to investigate whether the intestinal motor response to CCK is modified in $N$. brasiliensis postinfected rats. We also investigated the role of mast cell degranulation, CCK-A and CCK-B receptors and vagus nerves in the altered intestinal motor response to $\mathrm{CCK}$ in postinfected rats.

\section{MATERIALS AND METHODS}

\section{Animals}

Experiments were performed in 88 male Wistar rats (Harlan, Ganat, France) initially weighing between 150 and $200 \mathrm{~g}$. They were housed under controlled lighting conditions, with standard diet (A 04: Usine d'Alimentation Rationnelle, Epinay-sur-Orge, France) and water provided ad libitum. All protocols were approved by the Local Animal Care and Use Committee of Institut National de la Recherche Agronomique.

\section{Intestinal myoelectric studies}

Animals were prepared for long-term recordings of intestinal myoelectric activity with the use of a previously described technique. ${ }^{29}$ Briefly, under ketamine anaesthesia $120 \mathrm{mg} \mathrm{kg}^{-1}$ intraperitoneally (i.p.) (Imalgene 1000; Mérial, Lyon, France), two groups of three insulated $\mathrm{NiCr}$ wire electrodes $(80 \mu \mathrm{m}$ diameter, $80 \mathrm{~cm}$ length) were implanted in the wall of the proximal jejunum 5 and $15 \mathrm{~cm}$ distal to the ligament of Treitz. In 48 rats, a group of electrodes was also implanted in the proximal colon, $2 \mathrm{~cm}$ distal to the caeconcolonic junction. The jejunal sites were chosen according to the observation that $N$. brasiliensis is primarily implanted in the proximal half of the intestine and induces a mastocytosis, which is well established at this level at 30 days postinfection. ${ }^{30,31}$ The colonic site was considered as a control because no increase in mast cell numbers has been observed at this level after N. brasiliensis infection. ${ }^{30,31}$
Jejunal and colonic myoelectric activities were recorded with an electroencephalograph (Minihuit, Alvar, Paris, Francel, using a paper speed of $3.6 \mathrm{~cm} \mathrm{~min}^{-1}$ and a time constant of $0.03 \mathrm{~s}$. Jejunal spiking activity collected by bipolar derivation was summed every $20 \mathrm{~s}$ by an integrator circuit and automatically plotted on the $y$-axis of a potentiometric recorder (L 6514; Linseis, Selb, Germany) with a paper speed of $6 \mathrm{~cm} \mathrm{~h}^{-1}$. This integrated record permitted a clear determination of the cyclic occurrence of migrating myoelectric complexes (MMC) and of the duration of their disruption after administration of CCK.

\section{Subdiaphragmatic vagotomy}

In 12 rats, just before implantation of the electrodes, the anterior and posterior trunks of the vagus nerve were transected at $1 \mathrm{~cm}$ above the gastro-esophageal junction, as previously described. ${ }^{31}$ In 12 other rats, sham vagotomy was performed by a 5 min exteriorisation of the stomach from the abdominal cavity.

\section{Culture and infection techniques}

$N$. brasiliensis was maintained in continuous culture by harvesting worm eggs from infected rats and growing them to the third larval (L3) stage on vermiculite and filter paper, using a technique described by Jennings et al. ${ }^{32}$ The appropriate rats were infected by subcutaneously injecting $3,000 \mathrm{~L} 3$ infective larvae of $N$. brasiliensis in $0.5 \mathrm{~mL}$ sterile saline into the rat flank. Controls received sterile saline only.

\section{Experimental design}

For each series of experiment, treatments were applied in parallel to control and postinfected rats, then motility parameters were compared between the two animal populations where $n$ represented the number of animals in each group.

All studies were carried out between 30 and 50 days post- $N$. brasiliensis infection.

Soybean trypsin inhibitor (SBTI) and CCK-8 In a first series of experiments, in rats fasted for $14 \mathrm{~h}(n=6)$, soybean trypsin inhibitor (SBTI, 1\% solution $\mathrm{w} / \mathrm{v}$, $1 \mathrm{~mL}$ ) was administered by oro-gastric gavage (per oral; p.o.) when the myoelectrical activity of the jejunum displayed a MMC pattern. CCK-8 was administered i.p. at doses of $10(n=6)$ and $50 \mu \mathrm{g} \mathrm{kg}^{-1}$. For the dose of $50 \mu \mathrm{g} \mathrm{kg}^{-1}, \mathrm{CCK}$ was administered alone $(n=8)$ or after the vehicle $(0.2 \mathrm{~mL}$ DMSO i.p.; $n=8)$. 
Mast cell stabilization and depletion To assess the role of mast cells in the response to CCK- $8\left(50 \mu \mathrm{g} \mathrm{kg}^{-1}\right.$ i.p.) in controls and postinfected rats, two groups of rats were pretreated with the mast cell stabilizer, ketotifen (1 $\mathrm{mg} \mathrm{kg}^{-1}$ i.p.) and two other groups with the mast cell degranulator, $\operatorname{BrX} 537 \mathrm{~A}\left(2 \mathrm{mg} \mathrm{kg}^{-1} \text { i.p. }\right)^{33}$. Rats $\{n=8)$ received two injections of $\mathrm{BrX} 537 \mathrm{~A}$, at $14 \mathrm{~h}$ interval, the last one being performed $2 \mathrm{~h}$ before the administration of CCK- 8 . The other rats $(n=8)$ were given ketotifen twice daily for 4 days, and received the last administration $2 \mathrm{~h}$ before CCK- 8 . The dose of $2 \mathrm{mg} \mathrm{kg}^{-1}$ $\mathrm{BrX}$ 537.A was chosen because it was found to reduce the number of intestinal granulated mast cells 1 and $5 \mathrm{~h}$ after its administration to rats. ${ }^{33}$ The 4-day treatment with ketotifen twice daily at the dose of $1 \mathrm{mg} \mathrm{kg}^{-1}$ i.p. has previously been used to prevent mast cell degranulation in rats. ${ }^{34}$

Muscarinic and CCK receptor blockade Atropine (1 $\mathrm{mg} \mathrm{kg}^{-1}$ i.p.) was injected $30 \mathrm{~min}$ before CCK- 8 $\left(50 \mu \mathrm{g} \mathrm{kg}^{-1}\right.$ i.p.; $\left.n=6\right)$. The CCK-A receptor antagonist devazepide and the CCK-B antagonist L-365260 were administered i.p., at doses of 50,100 and $500 \mu \mathrm{g} \mathrm{kg}^{-1}$, $45 \mathrm{~min}$ before CCK-8 $\left(50 \mu \mathrm{g} \mathrm{kg}^{-1}\right.$ i.p.; $\left.n=8\right)$. CCK -8 (50 $\mu \mathrm{g} \mathrm{kg}^{-1}$ i.p.), preceded by the CCK receptor antag. onists $\left(100 \mu \mathrm{g} \mathrm{kg}^{-1}\right.$ i.p.) or their vehicle, was also administered in sham vagotomized $(n=6)$ and vagotomized rats $(n=6)$.

\section{Chemicals}

SBTI (type IIS; $1 \%$ solution $\mathrm{w} / \mathrm{v}$ ) was dissolved in distilled water containing carboxymethylcellulose 0.4 $\%$ w/v. Sulphated CCK-8, atropine sulphate and ketotifen fumarate were dissolved in sterile saline 0.9 $\%$. BrX 537A (bromolasalocid ethanolate), devazepide and L-365260 were dissolved in dimethylsulphoxide (DMSO). All compounds were obtained from Sigma (St Louis, MO, USA) except BrX 537A, which was a gift from Roche Laboratories (London, UK) and the CCK receptor antagonists, which were a gift from Merck Research Laboratories (Rahway, NJ, USA).

\section{Data analysis}

The duration of MMC disruption and the number of colonic contractions obtained after the different treatments were expressed as mean \pm SEM. Data from each group of animals were considered as resulting from one experiment and statistical analysis was performed using analysis of variance (ANOVA) followed by the Tukey's post hoc test. $P<0.05$ was considered statistically significant.

\section{RESULTS}

\section{Basal conditions}

In $14 \mathrm{~h}$-fasted control and postinfected rats, the intestinal motor profile consisted of MMC. The number of MMC for a $2 \mathrm{~h}$ period was $6.67 \pm 0.21 \mathrm{in}$ controis and $8.67 \pm 0.95(P>0.05)$ in postinfected rats. These values were not significantly modified after vagotomy in both groups (7.86 \pm 0.46 and $7.88 \pm 0.48$, respectively). At colonic level, the number of spike bursts for a $20 \mathrm{~min}$ period was $19.6 \pm 1.2$ in controls and $20.4 \pm 1$ in postinfected rats $(P>0.05)$.

\section{CCK-8 and SBTI}

In control animals, CCK- 8 administered i.p. at doses of 10 and $50 \mu \mathrm{g} \mathrm{kg}^{-1}$ disrupted the MMC pattern for $30.0^{\circ} \pm 5.8$ and $48.1 \pm 5.1 \mathrm{~min}$ respectively. These values were significantly increased in postinfected rats $(51.5 \pm 4.3$ and $95.5 \pm 3.5 \mathrm{~min}$, respectively; $P<0.05$ ) (Figs. 1A; 2A,B). After administration of the vehicle, $50 \mu \mathrm{g} \mathrm{kg}^{-1}$ CCK-8 i.p. disrupted the MMC pattern for $46.3 \pm 4.8$ and $99.3 \pm 4.6 \mathrm{~min}$ in controls and postinfected rats, respectively $(P<0.05)$ (Fig. $1 \mathrm{~A})$. At colonic level, $50 \mu \mathrm{g} \mathrm{kg}^{-1}$ CCK-8 i.p. decreased significantly $(P<0.05)$ the number of contractions for the first $20 \mathrm{~min}$ both in controls $(7.0 \pm 0.6)$ and postinfected rats $(6.9 \pm 0.6)$ compared with basal conditions.

Oral administration of SBTI $(1 \%$ solution w/v $; 1 \mathrm{~mL})$ immediately disrupted the MMC pattern which was replaced by a continuous activity for $21.7 \pm 4.6 \mathrm{~min}$ in controls and $44.7 \pm 6 \mathrm{~min}$ in postinfected rats $(P<0.05)$ (Fig. 1A). At colonic level, SBTI did not sig. nificantly modify the number of spike bursts for the first 20 min both in controls and postinfected rats $\{11.8 \pm 0.9$ and $12.1 \pm 2.2$, respectively, $P>0.05\}$ compared with basal conditions.

\section{Mast cell stabilization and depletion}

A pretreatment with the mast cell stabilizing agent ketotifen (1 $\mathrm{mg} \mathrm{kg}^{-1}$; 4 days, twice daily) did not significantly modify the MMC disruption induced by $50 \mu \mathrm{g} \mathrm{kg}^{-1}$ CCK-8 both in controls and postinfected rats $(47.9 \pm 4.9 \text { and } 89.0 \pm 9.5 \mathrm{~min} \text {, respectively })_{;}$ Figs. 1A, 2Cl. In the same conditions, previous administration of the mast cell degranulator BrX 537A (2 $\mathrm{mg} \mathrm{kg}^{-1}$, twice) did not significantly modify the duration of MMC disruption induced by CCK- 8 in both groups $(43.6 \pm 5.3$ and $88.9 \pm 3.6 \mathrm{~min}$, respectively; Fig. 1A). 

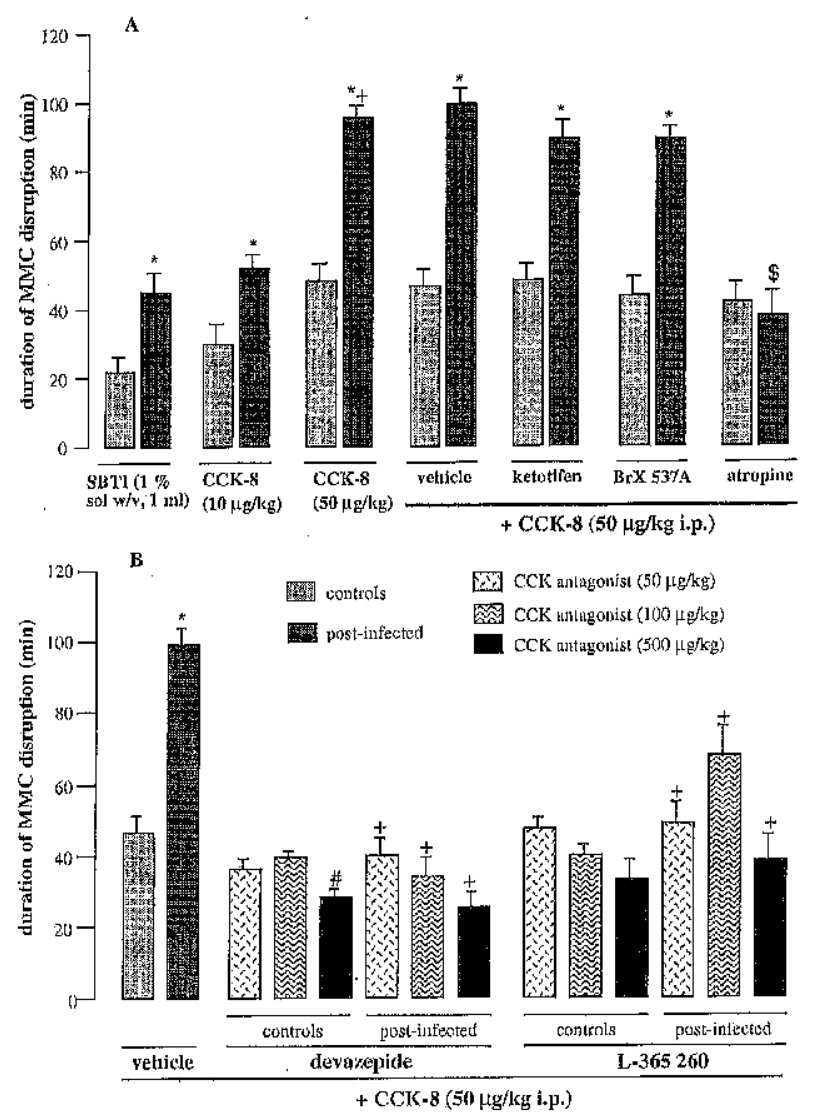

Figure 1 (A) Duration of $M M C$ disruption (min) after SBTI ( $1 \%$ solution $w / \mathrm{v}, 1 \mathrm{~mL} ; n=6)$ or CCK $-8\left(10 \mu \mathrm{gg}^{-1}\right.$ and $50 \mu \mathrm{g} \mathrm{kg}^{-1}$ i.p.; $n=6$ and 8) in controls and postinfected rats, after CCK-8 (50 $\mu \mathrm{g} \mathrm{kg}^{-1}$ i.p.) in vehicle-pretreated controls $(n=8)$ and postinfected rats $(n=8)$ or in controls and postinfected rats pretreated with ketotifen $\left(1 \mathrm{mg} \mathrm{kg}^{-1}\right.$ i.p., 4 days twice; $n=8)$ or $\operatorname{BrX} 537 \mathrm{~A}\left(2 \mathrm{mg} \mathrm{kg}^{-1}\right.$ i.p., twice; $\left.n=8\right)$, after CCK-8 $\left(50 \mu \mathrm{g} \mathrm{kg}^{-1}\right.$ i.p. $\}$ in atropine $\left(1 \mathrm{mg} \mathrm{kg}^{-1}\right.$ i.p.)-pretreated controls $(n=6)$ and postinfected rats $(n=6)$ (mean \pm SEM). ${ }^{*}$ Significantly different from the respective control group $(P<0,05) ;+$ significantly different from postinfected rats $(\mathrm{CCK}-8,10 \mu \mathrm{g} \mathrm{kg}-1$ i.p.; $P<0.05)$ \$Significantly different $(P<0.001)$ from vehicle-pretreated postinfected rats. $(B)$ Duration of MMC disruption (min) after CCK-8 $\left(50 \mu \mathrm{g} \mathrm{kg}^{-1}\right.$ i.p.) in vehicle-pretreated controls $(n=8)$ and postinfected rats $(n=8)$ or pretreated-rats with devazepide or L-365260 \$50, 100 or $500 \mu \mathrm{g} \mathrm{kg}^{-1}$ i.p., $\left.n=8\right)$ (mean \pm SEM). * Significantly different $(P<0.001)$ from the respective control group; +significantly different $\{P<0.01\}$ from vehicle-pretreated postinfected rats; \#Significantly different $(P<0.05)$ from vehicle-pretreated controls.

\section{Muscarinic and CCK receptor blockade}

The muscarinic receptor antagonist, atropine $\left(1 \mathrm{mg} \mathrm{kg}{ }^{-1}\right)$ did not reduce the effect of $50 \mu \mathrm{g} \mathrm{kg}^{-1}$ CCK- 8 in controls $(41.5 \pm 5.9 \mathrm{~min})$ but reduced it significantly
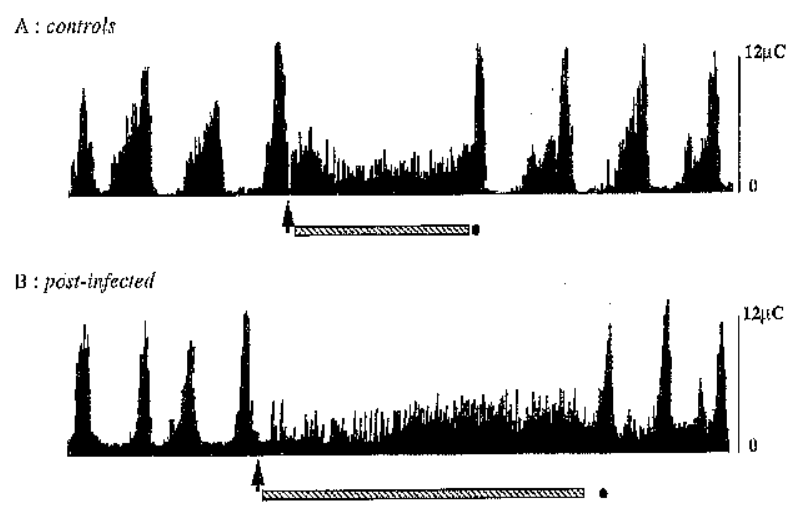

C: ketotifen-pretreated post-infected

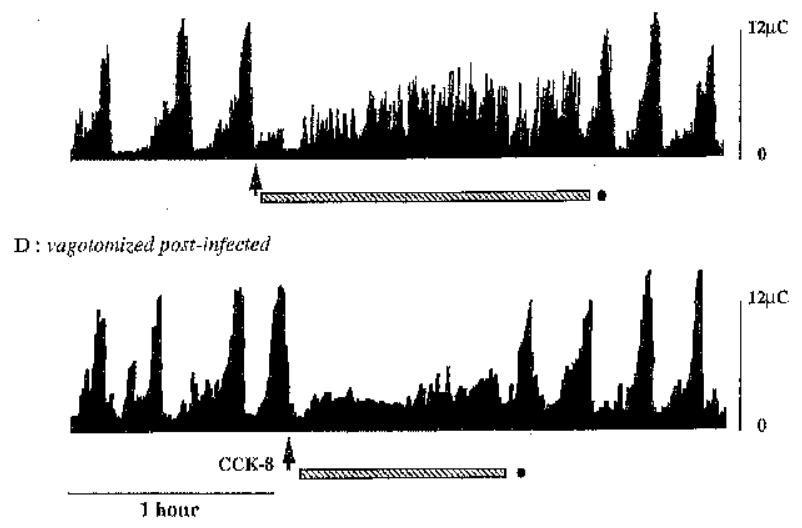

Figure 2 Representative integrated jejunal electromyograms obtained in control and post- $N$. brasiliensis-infected rats after i.p. administration of CCK-8 $\left(50 \mu \mathrm{g} \mathrm{kg}^{-1}\right)$, in basal conditions $(A-B)$, in postinfected rats pretreated with ketotifen $(\mathrm{C})$ or in vagotomized postinfected rats (D). Arrow, administration of CCK-8; bar, MMC disruption period; point, first phase III after MMC disruption.

$(P<0.001)$ in postinfected rats $\{37.7 \pm 7.0 \mathrm{~min}$; Fig. 1A).

The CCK-A receptor antagonist, devazepide, at 50 and $100 \mu \mathrm{g} \mathrm{kg}^{-1}$ did not significantly reduce the duration of MMC disruption induced by $50 \mu \mathrm{g} \mathrm{kg}^{-1} \mathrm{CCK}-8$ in controls $\{35.9 \pm 3.3$ and $39.6 \pm 1.6 \mathrm{~min}$, respectively, $P>0.05$ ) whereas the dose of $500 \mu \mathrm{g} \mathrm{kg}^{-1}$ significantly reduced this response $(28.3 \pm 2.1 \mathrm{~min}, P<0.05)$. In postinfected rats, devazepide at 50,100 and $500 \mu \mathrm{gg}^{-1}$ reduced the response to CCK- $8(40.0 \pm 4.4,33.8 \pm 5.7$ and $25.0 \pm 4.7 \mathrm{~min}$, respectively, $P<0.001$; Fig. $1 \mathrm{~B}$ ).

The CCK-B receptor antagonist, L-365260, at 50, 100 and $500 \mu \mathrm{g} \mathrm{kg}^{-1}$ did not shorten the MMC disruption induced by CCK -8 in controls $\{47.3 \pm 3,39.8 \pm 3.0$ and $32.8 \pm 6.0$ min, respectively, $P>0.051$ but reduced the response in postinfected rats $448.6 \pm 5.8, P<0.001$; $67.8 \pm 8.0, P<0.01$ and $38.3 \pm 7.1 \mathrm{~min}, P<0.001$, respectively) (Fig. 1B). 


\section{Role of the vagus nerve}

A bilateral vagotomy did not reduce the response to $50 \mu \mathrm{g} \mathrm{kg}{ }^{-1}$ CCK-8 in controls $\{50.0 \pm 2.7 \mathrm{~min}, P>0.05)$ but reduced it in postinfected rats $(43.3 \pm 7.6 \mathrm{~min}$, $P<0.001$ ) compared with sham vagotomized controls and postinfected rats $(45.0 \pm 0.9$ and $88.5 \pm 5.6 \mathrm{~min}$, respectively; Figs $3,2 \mathrm{D}$ ). In vagotomized control rats, devazepide and L-365260 at the dose of $100 \mu \mathrm{g} \mathrm{kg}^{-1}$ did not significantly reduce the response to CCK- 8 $\{23.3 \pm 7.3 \mathrm{~min}$ and $43.3 \pm 0.8 \mathrm{~min}, \quad$ respectively; $P>0.051$. In vagotomized postinfected rats, devazepide and L-365260 (100 $\left.\mu \mathrm{g} \mathrm{kg}^{-1}\right)$ did not significantly reduce the response to CCK $-8(37.5 \pm 3.5$ and $38.5 \pm 5.0 \mathrm{~min}$, respectively, $P>0.05$; Fig. 3 ).

\section{DISCUSSION}

Our results indicate that the neuroimmune changes of the intestinal wall which follow the inflammation induced by $N$. brasiliensis are associated, between 30 and 60 days postinfection, with a longer intestinal
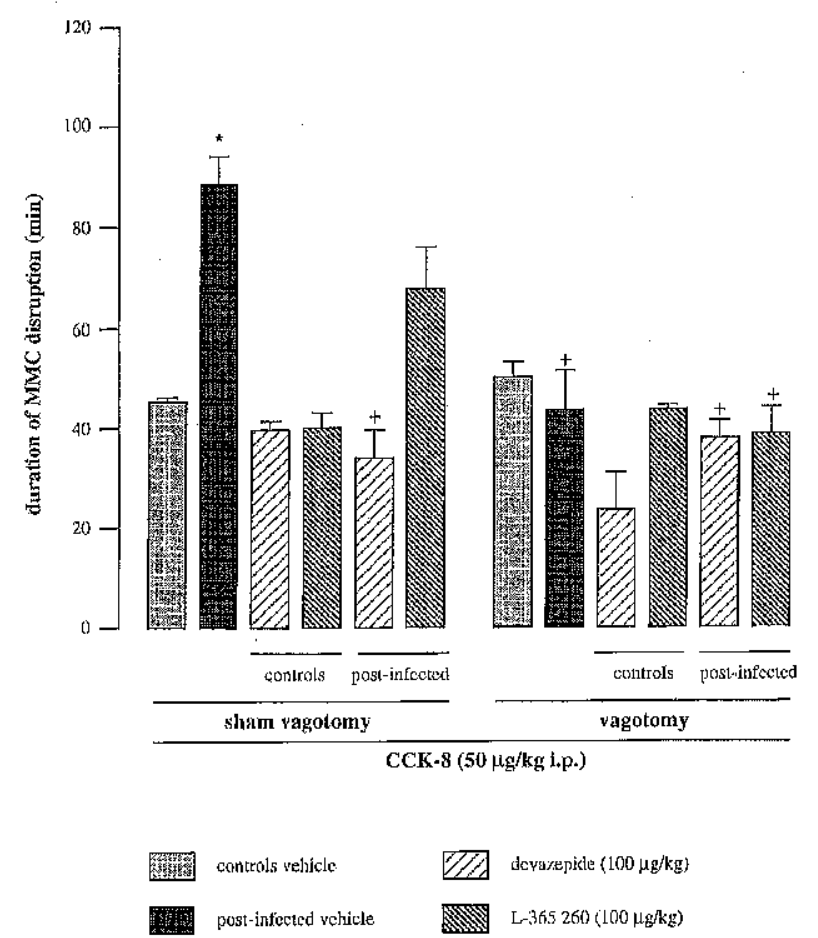

Figure 3 Duration of MMC disruption (min) after CCK-8 $\left\{50 \mu \mathrm{g} \mathrm{kg}^{-1}\right.$ i.p.) in sham vagotomized $(n=6)$ and vagotomized controls $(n=6)$ and postinfected rats $(n=6)$ pretreated with vehicle, devazepide or L-365260 (100 $\mu \mathrm{g} \mathrm{kg}^{-1}$ i.p.) (mean $上$ SEM). "Significantly different $(P<0.001)$ from sham vagotomized vehicle-pretreated controls; +significantly different $(P<0.001)$ from sham vagotomized vehicle-pretreated postinfected rats. motor response to both exogenous $\mathrm{CCK}$ and substancereleasing endogenous CCK. This increased reactivity to CCK appears to be limited to the jejunum, and to involve CCK-A and CCK-B receptors, the vagus nerve and a cholinergic mechanism.

In rats, infection with the nematode $N$. brasiliensis is a widely used model for the study of immune reactions of the gut. We have used this model for the study of long-term neuro-immune changes induced by the infection. The parasite develops in the proximal small intestine and produces an early inflammatory phase which peaks at $10-12$ days after infection. ${ }^{28}$ It also induces an intestinal mast cell hyperplasia ${ }^{21}$ and nerve remodelling ${ }^{35,22}$ which persist for several weeks after the inflammation has resolved. Changes in gut neurotransmitter concentration have also been identified during $T$, spiralis infection. ${ }^{36}$

It has been previously shown that the basal intestinal motility pattern, with regular occurrence of $\mathrm{MMC}$, is disrupted during the acute phase of inflammation from the 4th day after infection and that a normal pattern is recovered around the 21 st day. ${ }^{28}$ We confirm that 30 days after infection the intestinal MMC pattern is normal. This indicates that the nerve remodelling observed at this postinfection period does not correspond to profound alterations in myenteric plexus as can occur after infection by the parasite Trypanosoma $\mathrm{cruzi}^{37}$ in Chagas' disease, where the regular occurrence of normal $\mathrm{MMC}$ is suppressed.

The enhanced intestinal motor response to CCK 8 after i.p. administration in postinfected rats was reproduced by oral administration of SBTI, which is a. potent stimulus for the release of CCK from the upper small intestine of the rat. ${ }^{38}$ The similar enhancement of the intestinal motor response after SBTI or CCK- 8 indicates that the intraperitoneal administration of CCK- 8 is relevant for the study of physiological actions of CCK in our model. However, at least in humans, endogenous CCK released after a meal includes several molecular forms, CCK- 8 being released in small amounts and CCK-58 or CCK-39 appearing as the major molecular form. ${ }^{39}$ Moreover, the biological activity of these forms are different, CCK-58 being five times more potent than CCK- 8 in releasing amylase from pancreatic acini. ${ }^{40}$ On the other hand, the doses of $10 \mu \mathrm{g} \mathrm{kg}^{-1}$ of CCK and of 10 $\mathrm{mg}$ of SBTI orally probably induce an increase in plasma CCK in the range of that induced by a balanced meal. Plasma CCK concentrations of around 3,9 and 6 pmol L-1 were observed after $4 \mu \mathrm{g} \mathrm{kg}^{-1}$ CCK- 8 i.p., $10 \mathrm{mg}$ SBTI orally and a balanced meal, respectively. ${ }^{41-43}$ We have shown in a previous study ${ }^{21}$ that the MMC disruption induced by a meal known to be a 
potent releaser of $\mathrm{CCK}$ was not different in control and postinfected rats, and this can be considered to contrast with the enhanced response to $\mathrm{CCK}$ observed in the present study. However, CCK is known to be involved at central and peripheral levels in the postprandial disruption of $\mathrm{MMC}^{13,12}$ but other numerous neuronal and hormonal mediators have also been found to be involved in this disruption.

The CCK-8-induced inhibition of colonic contraction observed in our study is consistent with previous data obtained in rats ${ }^{44}$ as well as in humans. ${ }^{45}$ No change in the inhibitory colonic motor response to CCK was observed in postinfected rats, in comparison with controls. This agrees with the noxious hypersensitivity found localized to the jejunum in postinfected rats. ${ }^{30}$ This jejunal localisation indicates that the alterations in the motor response to CCK depends upon the neuroimmune alterations induced by the parasite, with no change in mast cell numbers being observed at colonic level. ${ }^{30,21}$

Mast cell stabilization or depletion did not modify the MMC disruption induced by CCK- 8 in both control and postinfected rats. This is not in agreement with results from Juanola et al. ${ }^{16}$ showing that CCK disrupts MMC through a mechanism involving mast cell degranulation. However, this mechanism has been shown for endogenous $\mathrm{CCK}$, and, as there are different forms of $\mathrm{CCK}$ released ${ }^{39}$ with different biological activities, ${ }^{40}$ it cannot be extrapolated to the effects of exogenously administered CCK-8. Moreover, there is no direct evidence for mast cell degranulating proper. ties of $\mathrm{CCK}$, and the presence of $\mathrm{CCK}$ receptor on mast cell has not been investigated. Until now, all digestive alterations described in $N$. brasiliensis postinfected rats, such as the increased sensitivity to distension ${ }^{30}$ and the increased intestinal motor response to acetylcholine or neurokinin $\mathrm{A}^{21}$ have been found to involve the mast cell hyperplasia. The enhanced response to CCK can indeed be attributed to neuronal alterations in the intestinal wall.

A mediation by acetylcholine of the intestinal contractile action of CCK is well established ${ }^{46}$ and CCK is known to be a potent releaser of acetylcholine in the gastrointestinal tract. ${ }^{47}$ Moreover, a proportion of enteric neurones immunoreactive for choline acetyltransferase also show CCK immunoreactivity. ${ }^{48}$ Intestinal inflammation induced by $T$. spiralis in the rat has been shown to induce in smooth muscle/ myenteric plexus preparations an increase in uptake of the acetylcholine precursor, choline, associated with defects in acetylcholine storage and exocytosis ${ }^{49}$. These alterations have been considered as long-lasting and can presumably persist after the inflammation has resolved. They may be involved in the increased duration of the effect of CCK in postinfected rats.

Vagotomy abolished the enhanced jejunal motor response to CCK in postinfected rats. This is consistent with the activation of vagal afferents by $\mathrm{CCK}$ which is well-documented, and with several actions of CCK administered i.p., such as decrease in food intake ${ }^{50,51}$ or inhibition of gastric emptying ${ }^{52}$ which depend upon the integrity of the vagus. However, vagotomy did not modify the jejunal response to CCK in control rats but affected the response in postinfected rats which have jejunal mastocytosis. This observation agrees with the contact between vagal afferent nerve fibres and mast cells found in the rat small intestine. ${ }^{53}$ More generally, a role of the vagus nerve in the action of CCK in postinfected rats supports the role attributed to this nerve as a link between the immune and the central nervous system. ${ }^{54}$ Furthermore, the attenuation rather than elimination of the action of CCK in rats with subdiaphragmatic vagotomy suggests that the residual effect of CCK in vagotomized rats or rats treated with atropine is not due to actions carried by vagal fibres. Thus, we may hypothesize a role of the enteric nerve fibres as nerve remodelling has been described at this level. ${ }^{22}$

Our results point out the participation of CCK-A and CCK-B receptors in postinfected rats but only CCK-A receptors in controls. We found that both CCK-A and CCK-B receptor antagonists abolished the enhanced jejunal motor response to $\mathrm{CCK}$ in postinfected rats. These compounds had very few effects in control rats as only the CCK-A receptor antagonist devazepide significantly reduced the CCK response at the highest dose of $500 \mu \mathrm{g} \mathrm{kg}^{-1}$. In postinfected rats, the efficacy of both devazepide and L-3652,60 concurs with the presence of CCK-A and CCK-B receptors on smooth muscle cells $s^{55}$ and myenteric neurons. ${ }^{56}$ The efficacy of the antagonists in postinfected rats only indicates that the infection induced profound and long-lasting changes in the population of CCK receptors. However, there is no evidence for a role of intestinal inflammation in these changes. An autoradiographic study indicates no change in $\mathrm{CCK}$ receptors in ulcerative colitis or in Crohn's disease. ${ }^{57} \mathrm{~A}$ recent study in $\operatorname{man}^{58}$ has evidenced an altered CCK receptor structure in a subgroup of patients with gallstones. As both CCK-A and CCK-B receptors have been identified in the vagus nerve ${ }^{59}$ and as vagotomy abolishes the enhanced response to $\mathrm{CCK}$ in postinfected rats, it can be postulated that the changes in CCK receptors occur at the level of the vagus nerve. Devazepide or L-365260 lacked the ability to decrease the response to CCK-8 in vagotomized postinfected rats, confirming that CCK-A and CCK-B receptors are predominantly localized on vagal afferent fibres. 
In conclusion, the postinflammatory neuroimmune alterations of the jejunum induced by $N$. brasiliensis infection lead to a markedly increased jejunal motility response to CCK. This enhanced reactivity involves a cholinergic pathway, a vagal mediation and changes in CCK receptors, but does not depend upon the degranulation of overabundant intestinal mast cells.

\section{ACKNOWLEDGMENTS}

We thank C. Bétoulières and L. Ressayre for their skilful technical assistance in $N$. brasiliensis culture, INRA and the Fondation pour la Recherche Médicale (FRM) for financial support.

\section{REFERENCES}

1 Chaudhary NA, Truelove SC. The irritable colon syndrome: a study of clinical features, predisposing causes, and prognosis in 130 cases. Q J Med 1962; 616: 307-22.

2 Kellow JE, Phillips SF, Miller LJ, Zinsmeister AR, Dysmotility of the small intestine in irritable bowel syndrome. Gut 1988; 29: 1236-43.

3 Neal KR, Hebden I, Spiller R. Prevalence of gastrointestinal symptoms six months after bacterial gastroenteritis and risk factors for development of the irritable bowel syndrome: postal survey of patients. Br Med / 1997; 314: $779-82$

4. Collins SM. Inflammation in the irritable bowel syndrome. In: Mayer EA, Raybould $\mathrm{HE}$, eds, Basic and Clinical Aspects of Chronic Abdominal Pain Amsterdam: Elsevier. 1993: 3-28.

5 Weston AP, Biddle WL, Bhatia PS, Miner PB. Terminal ileal mucosal mast cells in irritable bowel syndrome. Dig Dis Sci 1993; 38: 1590-5.

6 Pang $X$, Boucher W, Triadafilopoulos G, Sant GR, Theoharides TC. Mast cell and substance P-positive nerve involvement in a patient with irritable bowel syndrome and interstitial cystitis. Urology 1996, 47: 436-8.

7 Talley N), Butterfield JH. Mast cell infiltration and degranulation in colonic mucosa in the irritable bowel syndrome. Am / Gastroenterol 1996; 91: 1675-6.

8 Stead RH, Dixon MF, Bramwell NH, Riddell RH, Bienenstock J. Mast cells are closely apposed to nerves in the human gastrointestinal mucosa. Gastroenterology 1989; 97: 575-85.

9 Fioramonti J, Fargeas MJ, Bertrand V, Pradayrol L, Buéno L. Induction of postprandial intestinal motility and release of cholecystokinin by polyamines in rats. Am I Physiol 1994; 267: G960-G965.

10 Thor P, Laskiewicz J, Konturek P, Konturek SJ. Cholecystokinin in the regulation of intestinal motility and pancreatic secretion in dogs. Am / Physiol 1988; 255: G498-G504.

11 Buéno L, Ferre JP. Central regulation of intestinal motility by somatostatin and cholecystokinin octapeptide. Science 1982; 216: 1427-9.

12 Rodriguez-Membrilla A, Martinez V, Vergara P. Peripheral and central cholecystokinin receptors regulate postpran- dial intestinal motility in the rat. / Pharmacol Exp Ther 1995; 275: 486-93.

13 Liberge $M$, Arruebo P, Buéno L. CCK-8 neurons of the ventromedial (VMH) hypothalamus mediate the upper gut motor changes associated with feeding in rats. Brain Res 1990; 508: 118-23.

14 Fargeas MJ, Bassotti G, Fioramonti J, Buéno L. Involvement of different mechanisms in the stimulatory effects of cholecystokinin octapeptide on gastrointestinal and colonic motility in dogs. Can / Physiol Pharmacol 1989, 67: $1205-12$.

15 Rodriguez-Membrilla A, Vergara P. Endogenous CCK disrupts the MMC pattern via capsaicin-sensitive vagal afferent fibers in the rat. An I Physiol 1997, 272: G100-G105.

16 Juanola C, Giralt $M$, Jimenez $M$, Mourelle $M$, Vergara P. Mucosal mast cells are involved in CCK disruption of MMC in the rat intestine. Am I Physiol 1998; 275; G63-G67.

17 Roberts-Thomson IC, Fettman MJ, Jonsson JR, Frewin DB. Responses to cholecystokinin octapeptide in patients with functional abdominal pain syndromes. I Gastroenterol Hepatol 1992; 7: 293-7.

18 Arizono N, Yamada $M$, Tegoshi $T$, Okada $M$, Uchikawa $R$, Matsuda S. Mucosal mast cell proliferation following normal and heterotopic infections of the nematode Nippostrongylus brasiliensis in rats. APMIS. 1994; 102: 589-96.

19 Newlands GF, Miller HR, MacKellar A, Galli S). Stem cell factor contributes to intestinal mucosal mast cell hyperplasia in rats infected with Nippostrongylus brasiliensis or Trichinella spiralis, but anti-stem cell factor treatment decreases parasite egg production during $N$. brasiliensis infection. Blood 1995; 86: 1968-76.

20 Arizono N, Nalkao S. Kinetics and staining properties of mast cells proliferating in rat small intestine tunica muscularis and subserosa following infection with Nippostrongylus brasiliensis. APMIS 1988; 96: 964-70.

21 Gay J, Fioramonti J, Garcia-Villar R, Buéno L. Alterations in intestinal motor responses to various stimuli after nematode infection in rats: role of mast cells. Neurogastroenterol Motil 2000; 12: 207-14.

22 Stead RH. Nerve remodelling during intestinal inflammation. Ann N Y Acad Sci 1992; 664: 443-55.

23 Frieling T, Palmer JM, Cooke HI, Wood JD. Neuroimmune communication in the submucous plexus of guinea pig colon after infection with Trichinella spiralis, Gastroenterology 1994; 107: 1602-9.

24 Swain MG, Agro A, Blennerhassett P, Stanisz A, Collins $S M$. Increased levels of substance $P$ in the myenteric plexus of Trichinella-infected rats. Gastroenterology 1992; 102; 1913-9.

25 Masson SD, McKay DM, Stead RH, Agro A, Stanisz A, Perdue MH. Nippostrongylus brasiliensis infection evokes neuronal abnormalities and alterations in neurally regulated electrolyte transport in rat jejunum. Parasitology 1996; 113: $173-82$.

26 Stead RH, Tomioka M, Quinonez $\mathrm{G}$, Simon GT, Felten $S Y$, Bienenstock J. Intestinal mucosal mast cells in normal and nematode-infected rat intestines are in intimate contact with peptidergic nerves. Proc Natl Acad Sci USA 1987; 84: 2975-9.

27 McLean PG, Picard C, Crarcia-Villar R et al. Role of kinin $B 1$ and B2 receptors and mast cells in post intestinal 
infection-induced hypersensitivity to distension. Netzrogastroenterol Motil 1998; 10: 499-508.

28 Castex N, Fioramonti J, de Ducos Lahitte J, Luffau G, More $\mathrm{J}$, Buéno L. Brain Fos expression and intestinal motor alterations during nematode-induced inflammation in the rat. Am I Physiol 1998; 274: G210-G216.

29 Ruckebusch M, Fioramonti J. Electrical spiking activity and propulsion in small intestine in fed and fasted rats. Gastroenterology 1975; 68: 1500-8.

30 McLean P, Picard C, Garcia-Villar R, More J, Fioramonti J, Buéno $\mathrm{L}$. Effects of nematode infection on sensitivity to intestinal distension: role of tachykinin NK2 receptors. Eur I Phannacol 1997; 337: 279-82.

31 Watkins LR, Wiertelak EP, Goehler LE et al. Neurocircuitry of illness-induced hyperalgesia. Brain Res 1994, 639: 283-99.

32 Jennings FW, Mulligan W, Urquhart GM. Variables in $\mathrm{X}$-ray inactivation of Nippostrongylus brasiliensis larvae. Exp Parasitol 1963; 13: 367-73.

33 Castex N, Fioramonti J, Fargeas MJ, More J, Buéno L. Role of 5-HT3 receptors and afferent fibers in the effects of mast cell degranulation on colonic motility in rats. Gastroenterology 1994; 107: 976-84.

34 Pothoulakis C, Karmeli F, Kelly CP et al. Ketotifen inhibits Clostridium difficile toxin A-induced enteritis in rat ileum. Gastroenterology 1993, 105: 701-7.

35 Stead RH, Kosecka-Janiszewska U, Oestreicher AB, Dixon MF, Bienenstock J. Remodelling of B-50 (GAP-43)- and NSE-immunoreactive mucosal nerves in the intestine of rats infected with Nippostrongylus brasiliensis. I Neturosci 1991; 11: 3809-21.

36 Palmer IM, Greenwood B. Regional content of enteric substance $P$ and vasoactive intestinal peptide during intestinal inflammation in the parasitized ferret. Neuropeptides 1993 ; 25: 95-103.

37 Oliveira RB, Meneghelli UG, De Godoy RA, Dantas RO, Padovan W. Abnormalities of interdigestive motility of the small intestine in patients with Chaga's disease. Dig Dis Sci 1983; 28: 294-9.

38 Brand SJ, Morgan RG. The release of rat intestinal cholecystokinin after oral trypsin inhibitor measured by bioassay. I Physiol (Lond) 1981; 319: 325-43.

39 Eysselein VE, Eberlein GA, Hesse WH et al. Molecular variants of cholecystokinin after endogenous stimulation in humans: a time study. Am J Physiol 1990; 258: G951-G957.

40 Reeve JR, Eysselein VE, Rosenquist G et al. Evidence that CCK-58 has structure that influences its biological activity. Am I Physiol 1996; 270: G860-G868.

41 Smith GP, Greenberg D, Falasco ID et al. Endogenous cholecystokinin does not decrease food intake or gastric emptying in fasted rats. Am I Physiol 1989; 257: R1462-R1466.

42 Liddle RA, Green GM, Conrad CK, Williams JA, Proteins but not amino acids, carbohydrates, or fats stimulate cholecystokinin secretion in the rat. Am / Physiol 1986; 251: G243-G248.

43 Liddle RA, Goldfine ID, Williams JA. Bioassay of plasma cholecystokinin in rats: effects of food, trypsin inhibitor, and alcohol. Gastroenterology 1984; 87: 542-9.
44 Machino $\mathrm{H}$, Kobayashi $\mathrm{H}$, Hayashi $\mathrm{K}$, Tawara $\mathrm{Y}$, Ito $\mathrm{M}$, Kishimoto $\mathrm{S}$. Nitric oxide is involved in the inhibitory action of cholecystokinin octapeptide (CCKOP) on proximal colonic motility, Regul Pept 1997; 69: 47-52.

45 Mangel AW, Brazer SR, Smith JW, Fitz JG, Taylor IL. Inhibition of colonic motility by cholecystokinin. Ann Med 1992; 24: 341-2.

46 Vizi SE, Bertaccini G, Impicciatore $M$, Knoll J. Evidence that acetylcholine released by gastrin and related polypeptides contributes to their effect on gastrointestinal motility. Gastroenterology 1973; 64: 268-77.

47 Nilsson S, Leander S, Vallgren S, Hakanson R. Gastrins and cholecystokinins release acetylcholine but not substance $P$ from neurons in the guinea pig taenia coli. Eur I Pharmacol 1983, 90: 245-50.

48 Furness JB, Costa M, Keast JR. Choline acetyltransferase and peptide immunoreactivity of submucous neurons in the small intestine of the guinea pig. Cell Tissue Res 1984; 237: 329-36.

49 Davis KA, Masella J, Blennerhassett MG. Acetylcholine metabolism in the inflamed rat intestine. Exp Neurol 1998; 152: $251-8$

50 Moran TH, Baldessarini AR, Salorio CF, Lowery T, Schwartz GJ. Vagal afferent and efferent contributions to the inhibition of food intake by cholecystokinin. Am I Physiol 1997; 272: R1245-R1251.

51 Reidelberger RD. Abdominal vagal mediation of the satiety effects of exogenous and endogenous cholecystokinin in rats. Am J Physiol 1992; 263: R1354-R1358.

52 Raybould HE, Tache Y. Cholecystokinin inhibits gastric motility and emptying via a capsaicin-sensitive vagal pathway in rats. Am / Physiol 1988; 255: G242-G246.

53 Williams RM, Berthoud HR, Stead RH. Vagal afferent nerve fibres contact mast cells in rat small intestinal mucosa. Neturoimmunomodulation 1997, 4: 266-70.

54 Goehler LE, Gaykema RP, Nguyen KT et al. Interleukin-1 beta in immune cells of the abdominal vagus nerve: a link between the immune and nervous systems? I Neurosci 1999; 19: 2799-806.

55 de Weerth $A$, von Schrenck T, Gronewold $M$ et al. Characterization of CCK receptors in stomach smooth muscle: evidence for two subtypes. Biochim Biophys Acta 1997; 1327: 213-21.

56 Schutte IW, Alkkermans LM, Kroese AB. CCK-A and CCK-B receptor subtypes both mediate the effects of CCK-8 on myenteric neurons in the guinea pig ileum. / Auton NerV Syst 1997; 67: 51-9.

57 Mantyh PW, Catton MD, Boehmer CG et al. Receptors for sensory neuropeptides in human inflammatory diseases: implications for the effector role of sensory neurons. Peptides 1989, 10: 627-45.

58 Schneider H, Sanger P, Hanisch E. In vitro effects of cholecystokinin fragments on human gallbladders. Evidence for an altered CCK-receptor structure in a subgroup of patients with gallstones. I Hepatol 1997; 26: 1063-8.

59 Moriarty P, Dimaline R, Thompson DG, Dockray GJ. Characterization of cholecystokinin $\mathrm{A}$ and cholecystokinin B receptors expressed by vagal afferent neurons. Neuroscience 1997; 79: 905-13. 